Article

\title{
Analysis of Nitrogen Utilization Capability during the Proliferation and Maturation Phases of Norway Spruce (Picea abies (L.) H.Karst.) Somatic Embryogenesis
}

\author{
Julia Dahrendorf ${ }^{1}$, David Clapham ${ }^{2}$ and Ulrika Egertsdotter ${ }^{1,3, *}$ \\ 1 Umeå Plant Science Centre, Department of Forest Genetics and Plant Physiology, Swedish University of \\ Agricultural Sciences, SE-901 83 Umeå, Sweden; j.dahrendorf12@gmail.com \\ 2 BioCentre, Swedish University of Agricultural Sciences, SE-750 07 Uppsala, Sweden; David.Clapham@slu.se \\ 3 G.W. Woodruff School of Mechanical Engineering, Georgia Institute of Technology, Atlanta, GA 30332, USA \\ * Correspondence: Ulrika.Egertsdotter@slu.se; Tel.: +1-404-663-6950
}

Received: 1 April 2018; Accepted: 22 May 2018; Published: 24 May 2018

check for updates

\begin{abstract}
Somatic embryogenesis (SE) is a laboratory-based method that allows for cost-effective production of large numbers of clonal copies of plants, of particular interest for conifers where other clonal propagation methods are mostly unavailable. In this study, the effect of L-glutamine as an organic nitrogen source was evaluated for three contrasted media (containing $\mathrm{NH}_{4}+\mathrm{NO}_{3}$ without glutamine, or glutamine $+\mathrm{NO}_{3}$, or glutamine without inorganic nitrogen) during proliferation and maturation of Norway spruce somatic embryos through analyses of activities of the key enzymes of nitrogen metabolism: nitrate reductase (NR), glutamine synthetase (GS) and arginase. A major change in nitrogen metabolism was indicated by the increased activity of GS from zero in the proliferation stage through maturation to high activity in somatic embryo-derived plantlets; furthermore, NR activity increased from zero at the proliferation stage to high activity in maturing embryos and somatic-embryo derived plantlets. In contrast, arginase activity was high at all stages. In accordance with the GS and NR data, proliferation was fastest on the glutamine media, the largest number of mature embryos developed on the glutamine medium without inorganic nitrogen, and the ammonium content of proliferating cultures was much higher than that of mature somatic embryos. The best developed embryos, judged by germination, were from the glutamine $+\mathrm{NO}_{3}$ medium . These insights into nitrogen utilization will help to improve culture medium composition.
\end{abstract}

Keywords: conifers; somatic embryo development; ammonium; nitrate; glutamine; enzyme activities

\section{Introduction}

Norway spruce (Picea abies (L.) H.Karst.) is a key species for forest production in the Northern Hemisphere, including Sweden [1]. To meet the increased demand for wood products, propagation of superior trees from breeding programs is necessary [1,2]. This has usually required seed orchards, which are expensive and have problems with both pollen contamination and cone diseases [3], or clonal propagation by cuttings, which to date has had only limited success [1]. Somatic embryogenesis (SE) is a promising tool for large-scale clonal propagation that allows the capture of values from the breeding program [2]. Implementation of SE for large-scale plant production will benefit from further research and a better understanding of fundamental aspects of the SE process.

Conifers are able to take up both inorganic (nitrate, ammonia) and organic nitrogen sources (L-glutamine, L-arginine) [4,5]. Depending on which nitrogen form is supplied, the uptake preferences 
as well as effects on plant growth and development are different [6]. As opposed to most other species, conifers prefer ammonium over nitrate $[7,8]$.

The three key enzymes involved in nitrogen metabolism in higher plants are nitrate reductase (NR), glutamine synthetase (GS) and arginase. NR makes use of the nitrate taken up by the roots and converts it into nitrite, which is then further reduced to ammonia [9]; GS has a central role in nitrogen metabolism to re-assimilate ammonium from protein breakdown and assimilate ammonium: taken up from the soil, produced by nitrate reduction or from photorespiration [10]. Arginase plays a role in protein recycling to break down L-arginine to L-ornithine [9]. Along with L-glutamine, L-arginine is also an important amino acid in seed storage proteins [11].

Little is known about nitrogen metabolism during embryogenesis, and only few studies cover conifer embryogenesis. A comparison of zygotic and somatic embryogenesis in Pinus sylvestris L. and Pinus pinaster Aiton demonstrated GS1a expression in somatic, but not zygotic embryos at late developmental stages. Moreover, GS1b transcripts were found in the procambium of both zygotic and somatic embryos, suggesting the importance of GS1b for nitrogen transport [11]. In white spruce (Picea glauca (Moench) Voss), high concentrations of L-glutamine, L-glutamate and L-arginine were found in developing embryos [12].

Nitrogen use and preferences of nitrogen forms for uptake appear to differ between the early stages of embryo development and plant development in Norway spruce. It is well documented that seedlings of Norway spruce exhibit a preference for ammonium as an inorganic nitrogen source $[7,13]$. However, it has been shown repeatedly that proliferation of embryogenic cultures of Norway spruce is negligible with only inorganic nitrogen but strong after the addition of organic nitrogen in the form of L-glutamine [14] and references therein. A recent study of nitrogen uptake into proembryogenic masses (PEMs) of Norway spruce also demonstrated preferred uptake of organic nitrogen over inorganic nitrogen sources [15]. Casein hydrolysate can substitute for glutamine to some degree and is often added to culture media, providing a mixture of amino acids. It is usually added before autoclaving, which is convenient but breaks down the glutamine.

The aim of this study was to investigate the importance of L-glutamine as a nitrogen source during embryonic tissue proliferation and embryo development of Norway spruce by analyzing the relationship between activities of key enzymes involved in nitrogen metabolism, changes in ammonium and amino acid contents, and efficiency of somatic embryogenesis. Striking increases in the activity of GS and NR were observed from the proliferation stage through embryo maturation and the conversion to plantlets.

\section{Materials and Methods}

\subsection{Plant Material}

The embryogenic cell line 11:12:02 of Norway spruce, initiated from seeds provided by the Forestry Research Institute of Sweden, was used for most of the study. Additional cell lines, 11:07:01 and 09:86:02, used to confirm certain results, are of similar origin. Cultures were proliferated and embryos matured by standard methods on solid medium in 9-cm Petri plates [14]. Five plates of PEMs were used for each culture medium treatment for assays and four for culture; each plate contained one g of PEMs divided into nine clumps. Briefly, proliferation before start of the experiments was stimulated on modified half-strength LP medium (standard medium of Table 1) containing 2,4-dichlorophenoxyacetic acid (2,4-D; $10 \mu \mathrm{M})$, N6-benzyladenine (BA; $4.4 \mu \mathrm{M})$ and sucrose $(29.2 \mathrm{mM})$. After 6 weeks on the experimental proliferation media, the cultures were transferred to pre-maturation media for 1 week and then to maturation media for 6 weeks. The three experimental prematuration media corresponded to the three types of experimental proliferation media in Table 1 but without growth regulators and with sucrose concentration raised to $87.6 \mathrm{mM}$. Similarly, the maturation media corresponded to the experimental proliferation media of Table 1 but contained abscisic acid (ABA; $30 \mu \mathrm{M}$ ) as the only growth regulator and sucrose at $87.6 \mathrm{mM}$. Maturation was followed by two weeks on synchronization 
media, which were the same as the maturation media with the addition of $0.25 \mathrm{M}$ myo-inositol. Filter-sterilized glutamine was added to the medium after autoclaving. Proliferation, maturation and synchronization of SE cultures were on media solidified by gelrite (3.5\%) in Petri dishes. Cultures were kept in darkness at $20{ }^{\circ} \mathrm{C}$. Mature embryos, selected as normal based on their morphology [16], were dried for 3 weeks under high humidity in darkness and subsequently germinated in $15-\mathrm{cm}$ Petri dishes on solid medium; the germination medium was similar to the medium $\mathrm{NH}_{4}+\mathrm{NO}_{3}$ in Table 1 but included $\mathrm{KNO}_{3}(7.56 \mathrm{mM})$ and sucrose at $87.6 \mathrm{mM}$, and excluded the ammonium salts, $\mathrm{K}_{2} \mathrm{SO}_{4}$ and $\mathrm{KCl}$. The $\mathrm{pH}$ was adjusted to $5.8 \pm 0.1$ prior to autoclaving. Germinants were grown for 3 weeks under continuous red light (wavelength: $660 \mathrm{~nm}$; TL-D 18W/15, Philips, Stockholm, Sweden) at $5 \mu \mathrm{mol} \mathrm{m}{ }^{-2} \mathrm{~s}^{-1}$ at $20^{\circ} \mathrm{C}$, then moved under continuous white fluorescent tubes (Fluora $\mathrm{L}$ $18 \mathrm{~W} / 77$, Osram, Johanneshov, Sweden) at $100-150 \mu \mathrm{mol} \mathrm{m} \mathrm{m}^{-2} \mathrm{~s}^{-1}$ at $20^{\circ} \mathrm{C}$ [17]. Two-month old somatic embryo-derived plants and roots of cell line 11:12:02 were kindly provided by SweTree Technologies. The cultures were proliferated and matured by standard methods [14] and converted to plants on the same germination medium as described above.

Table 1. Mineral, organic nitrogen and vitamin composition of the standard and experimental media for proliferation of PEMs. Sucrose $(29.21 \mathrm{mM})$ and the growth regulators 2,4-D $(10 \mu \mathrm{M})$ and N6-benzylaminopurine $4.4 \mu \mathrm{M}$ were also included. Media were solidified with gelrite $\left(3.5 \mathrm{~g} \mathrm{~L}^{-1}\right)$. Casein hydrolysate $\left(0.5 \mathrm{~g} \mathrm{~L}^{-1}\right)$ was added before autoclaving, glutamine was added filter-sterilized after autoclaving.

\begin{tabular}{|c|c|c|c|c|}
\hline \multicolumn{5}{|c|}{ Experimental Media } \\
\hline Constituent & Standard & $\mathrm{NH}_{4}+\mathrm{NO}_{3}$ & $\mathrm{Gln}+\mathrm{NO}_{3}$ & Gln \\
\hline \multicolumn{5}{|c|}{ Concentration, $\mathrm{mM}$} \\
\hline $\mathrm{KNO}_{3}$ & 9.40 & 0 & 0 & 0 \\
\hline $\mathrm{NH}_{4} \mathrm{NO}_{3}$ & 3.75 & 0 & 0 & 0 \\
\hline $\mathrm{NaNO}_{3}$ & 0 & 26.58 & 26.58 & 0 \\
\hline $\mathrm{NH}_{4} \mathrm{Cl}$ & 0 & 3.46 & 0 & 0 \\
\hline $\mathrm{K}_{2} \mathrm{SO}_{4}$ & 0 & 0.72 & 0.72 & 0.72 \\
\hline $\mathrm{KCl}$ & 0 & 2.56 & 2.56 & 2.56 \\
\hline $\mathrm{MgSO}_{4} \cdot 7 \mathrm{H}_{2} \mathrm{O}$ & 0.75 & 0.77 & 0.77 & 0.77 \\
\hline $\mathrm{KH}_{2} \mathrm{PO}_{4}$ & 1.25 & 1.86 & 1.86 & 1.86 \\
\hline $\mathrm{CaCl}_{2} \cdot 2 \mathrm{H}_{2} \mathrm{O}$ & 1.50 & 0.74 & 0.74 & 0.74 \\
\hline \multicolumn{5}{|c|}{ Concentration, $\mu \mathrm{M}$} \\
\hline $\mathrm{FeSO}_{4} \cdot 7 \mathrm{H}_{2} \mathrm{O}$ & 45.75 & 91.5 & 91.5 & 91.5 \\
\hline $\mathrm{Na}_{2}$ EDTA & 25.02 & 50.03 & 50.03 & 50.03 \\
\hline Zn-EDTA & 5.004 & 0 & 0 & 0 \\
\hline $\mathrm{ZnSO}_{4} \cdot 7 \mathrm{H}_{2} \mathrm{O}$ & 0 & 29.91 & 29.91 & 29.91 \\
\hline KI & 2.26 & 5.00 & 5.00 & 5.00 \\
\hline $\mathrm{H}_{3} \mathrm{BO}_{3}$ & 5.09 & 100.26 & 100.26 & 100.26 \\
\hline $\mathrm{MnSO}_{4} \cdot 7 \mathrm{H}_{2} \mathrm{O}$ & 5.00 & 108.26 & 108.26 & 108.26 \\
\hline $\mathrm{NaMoO}_{4} \cdot 2 \mathrm{H}_{2} \mathrm{O}$ & 0.007 & 1.37 & 1.37 & 1.37 \\
\hline $\mathrm{CuSO}_{4} \cdot 5 \mathrm{H}_{2} \mathrm{O}$ & 0.001 & 0.16 & 0.16 & 0.16 \\
\hline $\mathrm{CoCl}_{2} \cdot 6 \mathrm{H}_{2} \mathrm{O}$ & 0.001 & 0.19 & 0.19 & 0.19 \\
\hline Pyridoxine & 2.95 & 0 & 0 & 0 \\
\hline Nicotinic acid & 8.12 & 0 & 0 & 0 \\
\hline Thiamine $\cdot \mathrm{HCl}$ & 7.41 & 2.9 & 2.9 & 2.9 \\
\hline \multicolumn{5}{|c|}{ Concentration, $\mathrm{mM}$} \\
\hline Myo-inositol & 1.25 & 0.28 & 0.28 & 0.28 \\
\hline L-Glutamine & 3.08 & 0 & 6.20 & 6.20 \\
\hline Casein hydrolysate & 0 & 3.90 & 3.90 & 3.90 \\
\hline
\end{tabular}




\subsection{Experimental Set $U p$}

The experimental media were designed to provide media with different nitrogen compositions (Table 1). The standard medium commonly used for Norway spruce somatic embryo development was used to bulk up proliferating cultures of proembryonic masses (PEMs).

Proliferation rates of PEMs and development of embryos on the various media were documented after ten days on proliferation medium, one week without plant growth regulators, after three weeks and six weeks on maturation medium, after two weeks on synchronization medium, as well as one week, two and a half weeks and four weeks after germination (Figure 1). Pictures were taken with a Nikon d5000 digital camera (Nikon Corporation, Tokyo, Japan), and microscopes (Stemi 2000-C, Zeiss, Germany with Canon Power Shot G9 and Observer.A1m, Zeiss, Germany with AxioCam MR3Zeiss, Germany). Microscope pictures were processed with the program Axiovision 4.6.3 (Axiovision 4.6.3. Carl Zeiss, Jena, Germany). The proliferation rate based on fresh weight gain during the two-week culture period, maturation success based on the average number of cotyledonary stage mature somatic embryos formed per gram of PEMs at the start of maturation, the germination rate as the number of mature embryos that germinated and germination quality based on visual observation with reference to previous successful conversions from germinants to plants were monitored. Samples for analyses of enzyme activities and ammonium and amino acids were taken at three occasions during embryo proliferation and development after transfer to experimental media (Figure 1).

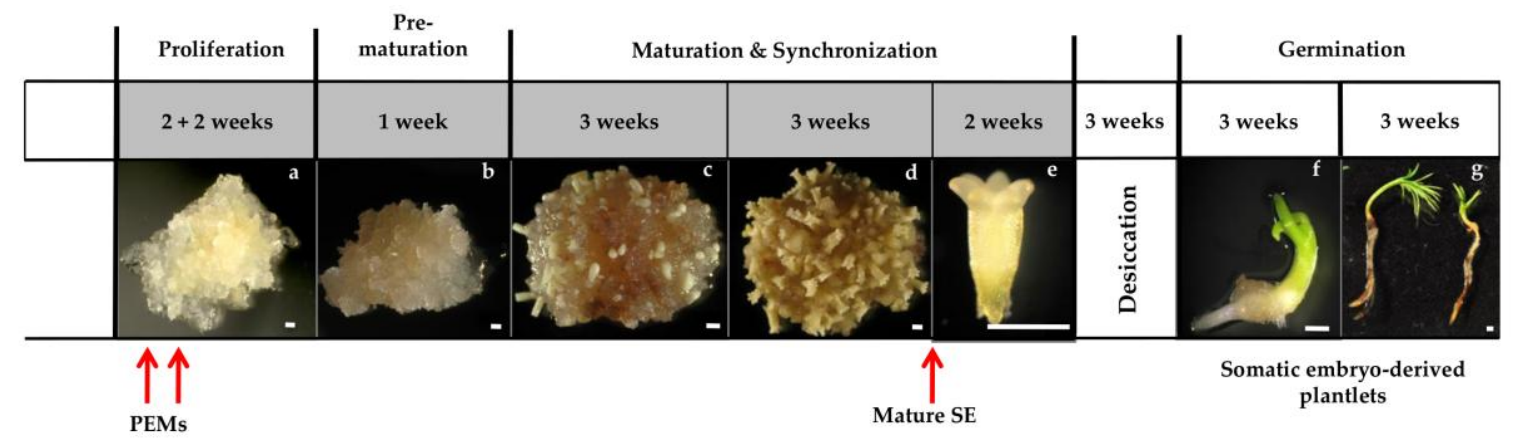

Figure 1. Overview of sampling during the somatic embryogenesis process in Norway spruce PEMs were sampled from experimental media after four and ten days (red arrows). Samples were taken after six weeks on maturation media (red arrow).

\subsection{Enzyme Assays}

Samples of $100 \mathrm{mg}$ of fresh material were taken after four and ten days on experimental proliferation media. After six weeks on experimental maturation medium, $70 \mathrm{mg}$ of fresh cotyledonary stage mature somatic embryos were collected. As reference for the enzyme assays, two-month-old somatic embryo-derived plantlets of cell line 11:12:02 were collected $(50 \mathrm{mg})$ and analyzed. A pool of twelve plantlets was used for one sample. For all samples, three to four biological replicates were analyzed, each with three technical replicates.

\subsubsection{GS Assay}

The protein extraction step for the GS assay is based on Canovas et al. 1991 [18]. The GS activity assay was determined by the hydroxamate assay described by Canovas et al. 1984 [19] with minor modifications.

Proteins were extracted by grinding frozen samples (from $-150{ }^{\circ} \mathrm{C}$ freezer, Panasonic Healthcare Ltd., Tokyo, Japan) with two metal beads for $1 \mathrm{~min}$ in a bead mill (Retsch MM400, Haan, Germany). Samples were homogenized in $900 \mu \mathrm{L}$ extraction buffer for another $1 \mathrm{~min}$ at $25 \mathrm{~Hz} \mathrm{~s}^{-1}$ in the bead mill. Cell debris was centrifuged at 10,000 $\times \mathrm{g}$ for $20 \mathrm{~min}$ at $4{ }^{\circ} \mathrm{C}$ (Eppendorf, Hamburg, Germany). 
The supernatant was used directly as a crude extract. Crude extracts were used for enzyme activity analysis: $40 \mu \mathrm{L}$ was transferred in triplicate to wells in a 96 well plate and mixed with $40 \mu \mathrm{L}$ of reaction mix. After incubation on a shaker for $30 \mathrm{~min}$ at $37^{\circ} \mathrm{C}$, the reaction was terminated by the addition of $40 \mu \mathrm{L}$ terminating mixture. Absorbance at $540 \mathrm{~nm}$ was measured by using a spectrophotometer (BioTek, Winooski, VT, USA, micro plate reader) for $5 \mathrm{~min}$. GS activity was expressed as $\mu \mathrm{g} \gamma$-glutamyl hydroxamate $\mathrm{mg}^{-1}$ protein. The protein concentration of the samples was determined by using the DC Protein Assay (BioRad, Hercules, CA, USA).

\subsubsection{NR Assay}

The NR assay was performed according to Park et al. 2011 [20]. Two-month old somatic embryo-derived plantlets and roots previously shown to have active NR [21] were included as positive controls for the assay. Proteins were extracted by grinding the frozen $\left(-150{ }^{\circ} \mathrm{C}\right)$ tissues with two beads for $1 \mathrm{~min}$ in the bead mill. Samples were homogenized in $1 \mathrm{~mL}$ extraction buffer for another minute at $25 \mathrm{~Hz} \mathrm{~s}^{-1}$ in the bead mill. Cell debris was centrifuged at $10,000 \times \mathrm{g}$ for $15 \mathrm{~min}$ at $4{ }^{\circ} \mathrm{C}$. The required amount of supernatant was directly used and the rest stored at $-20^{\circ} \mathrm{C}$. The supernatant $(100 \mu \mathrm{L})$ was mixed with $1.8 \mathrm{~mL}$ of assay reaction buffer and incubated at room temperature for $2 \mathrm{~h}$. The reaction was terminated by the addition of terminating reagent, and the color development was quantified by measuring with a BioTek micro plate reader the increase in absorbance at $540 \mathrm{~nm}$ (A540). NR activity is expressed as $\mathrm{A} 540 \mathrm{mg}^{-1}$ fresh weight over the time interval of $2 \mathrm{~h}$.

\subsubsection{Arginase Assay}

Arginase activity was determined based on production of urea according to Geyer and Dabich 1971 [22]. Proteins were extracted according to Martín-Falquina and Legaz [23]. The frozen samples were ground with two beads for $1 \mathrm{~min}$ in the bead mill. Samples were homogenized in $1 \mathrm{~mL}$ extraction buffer for another $1 \mathrm{~min}$ at $25 \mathrm{~Hz} \mathrm{~s}^{-1}$ in the bead mill. Cell debris was centrifuged at $10,000 \times g$ for $20 \mathrm{~min}$ at $4{ }^{\circ} \mathrm{C}$. The supernatant was used directly. Activation and deactivation of the arginase were performed by incubation of $100 \mu \mathrm{L}$ of the extracts at $30^{\circ} \mathrm{C}$ (activation) and $95^{\circ} \mathrm{C}$ (deactivation), respectively, for $1 \mathrm{~h}$ in a water bath. Enzyme reactions were started by the addition of $1.4 \mathrm{~mL}$ arginase assay buffer to the activated and deactivated samples and incubated for $30 \mathrm{~min}$ at $30{ }^{\circ} \mathrm{C}$. Reactions were terminated by the addition of $1.12 \mathrm{~mL}$ of $87 \%$ acetic acid. Color reagent $(2 \mathrm{~mL})$ and $3 \mathrm{~mL}$ acid reagent were added to each tube, and the mixture was heated in a water bath at $95{ }^{\circ} \mathrm{C}$ for ten minutes. Color development was detected by absorbance measurement at $520 \mathrm{~nm}$. Arginase activity is expressed as urea content per total protein content $\left(\mathrm{mg} \mathrm{mg}^{-1}\right.$ protein $\left.\mathrm{min}^{-1}\right)$. The protein concentration of the samples was measured using the BioRad DC Protein Assay.

\subsection{Ammonium and Amino Acid Content}

The analysis of the ammonium and amino acid content and composition was carried out with cell line 11:12:02. Three biological replicates of PEM cultures (50 mg) were collected 4 days and 10 days after transfer to the corresponding maturation media and stored at $-150{ }^{\circ} \mathrm{C}$ until analysis. Of these cultures, $30 \mathrm{mg}$ of cotyledonary stage mature somatic embryos were hand-picked after six weeks on each type of maturation medium and stored at $-150{ }^{\circ} \mathrm{C}$ until analysis. Three biological replicates were collected from all treatments. The ammonium and amino acid content of the samples were determined using the ACQUITY UPLC ${ }^{\circledR}$ (Ultra Performance Liquid Chromatography) Amino Acid Analysis System (Waters Corporation, Milford, MA, USA). The content of each amino acid in the sample is expressed as a ratio of the total amino acid content.

\subsection{Statistical Analysis}

Data were analyzed statistically with the program JMP version 10.0 (SAS Institute Inc., Cary, NC, USA). One-way ANOVA was applied for the proliferation rate, germination rate, enzyme activities, 
ammonium content and amino acid analysis. Results from different culture media compositions were compared by a Tukey-Kramer HSD test, cut-off at $p \leq 0.05$.

\section{Results}

\subsection{The Effect of Nitrogen Source on Somatic Embryogenesis}

\subsubsection{PEMs}

PEM cultures grown either on standard medium or experimental $\mathrm{NH}_{4}+\mathrm{NO}_{3}, \mathrm{Gln}+\mathrm{NO}_{3}$ and $\mathrm{Gln}$ media exhibited no differences in morphology and development ten days after transfer to experimental media (not shown). However, the proliferation rate of the PEMs differed, resulting in differences in fresh weight increase (Figure 2).

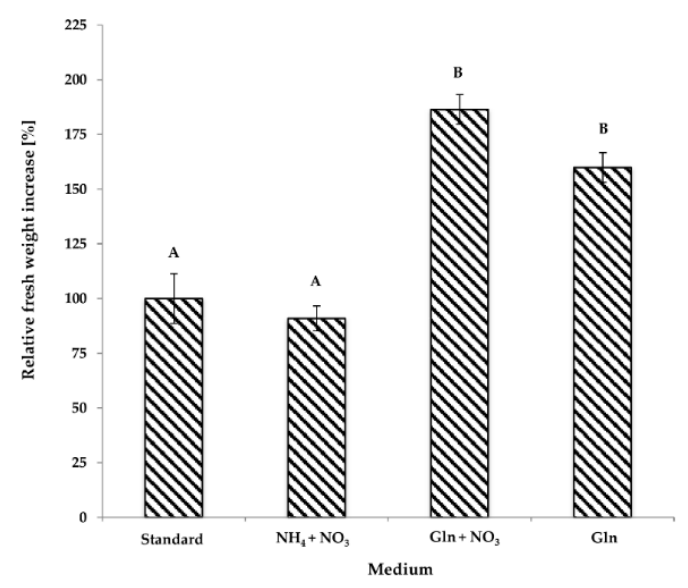

Figure 2. Relative fresh weight increase (\%) of PEM cultures after ten days on different proliferation media: standard medium, $\mathrm{NH}_{4}+\mathrm{NO}_{3}$ medium, $\mathrm{Gln}+\mathrm{NO}_{3}$ medium and Gln medium. Proliferation rates have been related to the standard medium. Bars indicate standard errors. Different letters above the columns indicate significant differences based on the Tukey-Kramer HSD test, $p \leq 0.05$.

PEM cultures on standard medium or $\mathrm{NH}_{4}+\mathrm{NO}_{3}$ medium did not reveal any statistically significant difference in proliferation rate on the two media (Figure 2). However, PEM cultures grown on $\mathrm{Gln}+\mathrm{NO}_{3}$ and Gln media showed significantly improved growth of around $80 \%$ greater increase in fresh weight compared to PEMs on standard medium.

\subsubsection{Maturation}

After six weeks on maturation medium with ABA and two weeks on synchronization medium, mature somatic embryos had developed on all the media. However, the size and developmental stage of the somatic embryos differed among the media containing different nitrogen sources.

The largest and most developed somatic embryos with prominent cotyledons were observed on $\mathrm{Gln}+\mathrm{NO}_{3}$ medium (Figure 3d-f). Somatic embryos comparable in stage of development, though smaller in size, developed on $\mathrm{NH}_{4}+\mathrm{NO}_{3}$ medium (Figure 3a-c). If matured on Gln medium, somatic embryos were small and many showed brown spots on the cotyledons (Figure $3 \mathrm{~g}-\mathrm{i}$ ). The average number of mature somatic embryos per initial gram of PEMs started on maturation medium was significantly higher on Gln medium than on both the $\mathrm{Gln}+\mathrm{NO}_{3}$ medium and $\mathrm{NH}_{4}+\mathrm{NO}_{3}$ medium (Figure 4). 


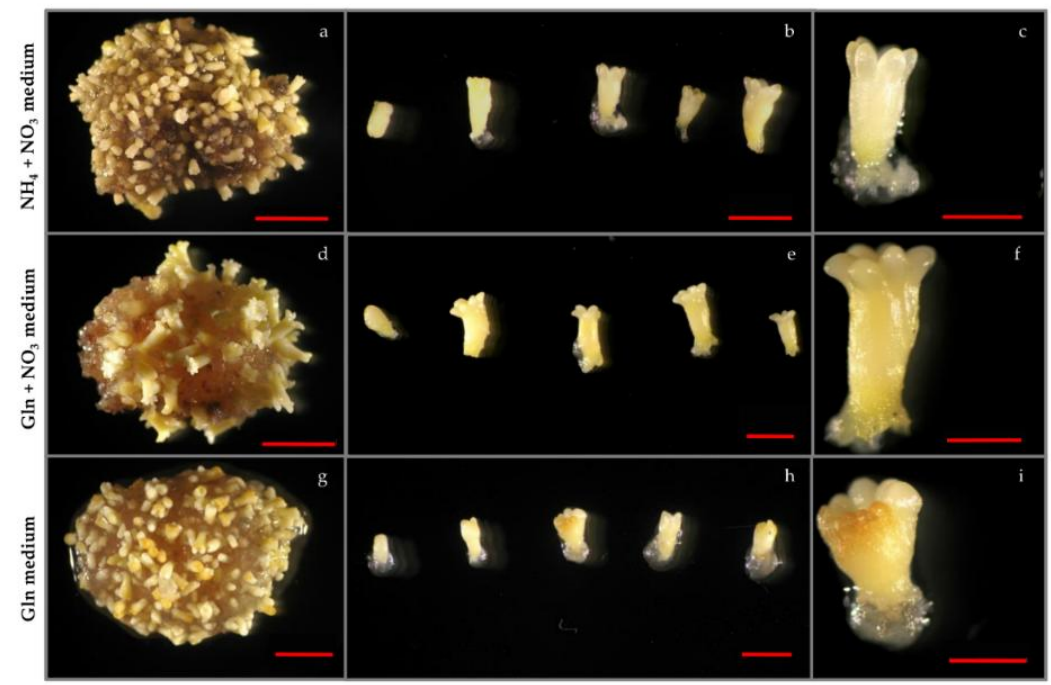

Figure 3. Mature somatic embryos of Norway spruce cell line 11:12:02 after six weeks on maturation media followed by two weeks on corresponding synchronization media: (a-c) $\mathrm{NH}_{4}+\mathrm{NO}_{3}$; (d-f) $\mathrm{Gln}+\mathrm{NO}_{3}$ and $(\mathbf{g}-\mathbf{i})$ Gln. Left bars $=5 \mathrm{~mm}$; middle bars $=2 \mathrm{~mm}$; right bars: $1 \mathrm{~mm}$.

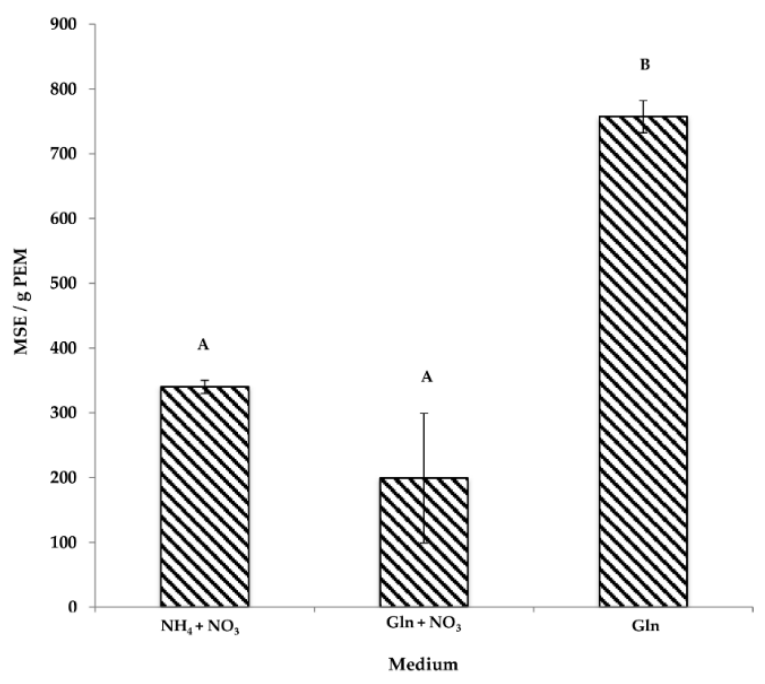

Figure 4. Average number of mature somatic embryos (MSE) developed per gram of PEMs on $\mathrm{NH}_{4}+\mathrm{NO}_{3}$ medium, Gln $+\mathrm{NO}_{3}$ medium and Gln medium after eight weeks with ABA. Different letters above the columns indicate significant differences based on the Tukey-Kramer HSD test, $p \leq 0.05$.

\subsubsection{Germination}

Only somatic embryos with well-developed cotyledons were manually picked, desiccated and transferred to germination medium. After four weeks of germination, morphological differences related to the nitrogen sources in the maturation medium were evident (Figure 5). Somatic embryos matured on Gln $+\mathrm{NO}_{3}$ medium developed slightly better than those matured on $\mathrm{NH}_{4}+\mathrm{NO}_{3}$. Those matured on Gln showed impaired development with only rudimentary root development and often dead shoots. The germination rate was highest after maturation on Gln $+\mathrm{NO}_{3}$ medium (90\% of total 608 mature embryos), intermediate on $\mathrm{NH}_{4}+\mathrm{NO}_{3}$ medium $(82.1 \%$ of total 1021 mature embryos) and lowest after maturation on Gln medium (74.5\% of total 2266 mature embryos). Plantlets with the healthiest shoots and roots developed from embryos matured on $\mathrm{Gln}+\mathrm{NO}_{3}$ medium, followed 
by those matured on $\mathrm{NH}_{4}+\mathrm{NO}_{3}$. Germinating embryos matured on Gln medium showed the least normal plant development.

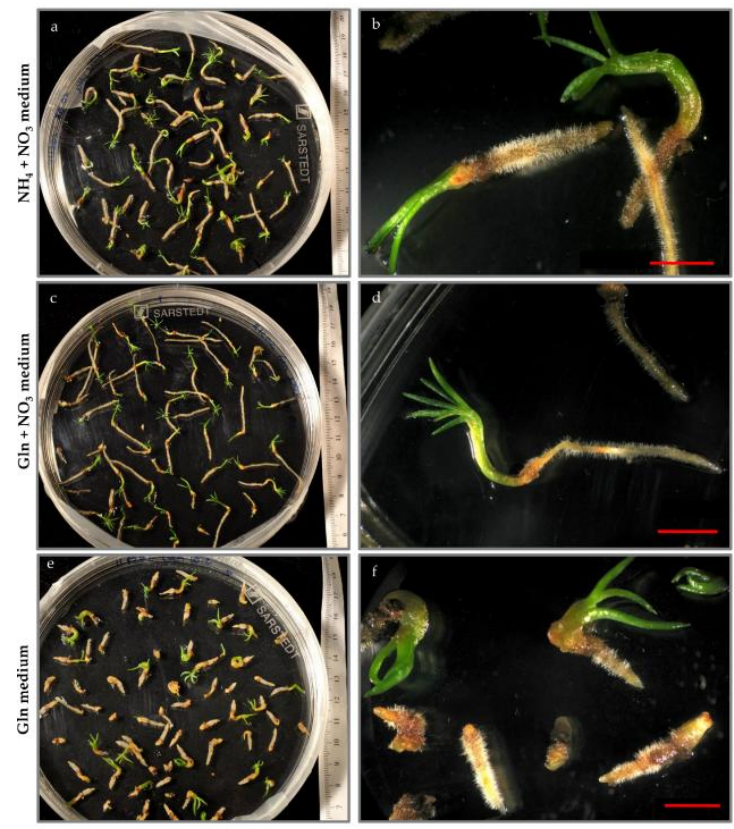

Figure 5. Germination of mature somatic embryos after four weeks on germination medium. Mature embryos were generated on $(\mathbf{a}, \mathbf{b}) \mathrm{NH}_{4}+\mathrm{NO}_{3}$ medium; $(\mathbf{c}, \mathbf{d}) \mathrm{Gln}+\mathrm{NO}_{3}$ medium; (e,f) Gln medium. Upper bars $=2 \mathrm{~mm}$; middle and lower bars $=5 \mathrm{~mm}$.

\subsection{Enzyme Activities}

\subsubsection{GS Activity}

No GS activity was observed for PEMs of cell line 11:12:02 harvested after four days and ten days on standard and experimental media (Figure 6). Another cell line (09:86:02) analyzed under the same conditions also showed no measurable GS activity (data not shown). GS activity of about $200 \mu \mathrm{g} \gamma$-glutamyl hydroxamate $\mathrm{min}^{-1} \mathrm{mg}^{-1}$ protein was detected in the two-month-old somatic embryo-derived plantlets. This is statistically significant compared to the enzyme activity in mature somatic embryos. The GS activity in mature somatic embryos was confirmed in the other cell line tested, 11:07:01 (Figure S1).

\subsubsection{NR Activity}

The NR activity detected in cultures of PEMs harvested four days and ten days after transfer to standard or experimental media was zero, like that of GS. Similar results were obtained for PEMs of another cell line (09:86:02) analyzed in parallel (data not shown).

Somatic embryos matured on $\mathrm{NH}_{4}+\mathrm{NO}_{3}$ medium or on Gln medium showed no statistically significant difference in NR activity. Somatic embryos matured on $\mathrm{Gln}+\mathrm{NO}_{3}$ medium exhibited a significantly higher $\mathrm{NR}$ activity compared to embryos matured on $\mathrm{NH}_{4}+\mathrm{NO}_{3}$ medium and embryos matured on Gln medium (Figure 7). The NR activity in embryos matured on Gln $+\mathrm{NO}_{3}$ medium was also statistically significantly higher than the NR activity found in somatic embryo-derived plantlet roots, and higher, but not significantly so, than in plantlets. 


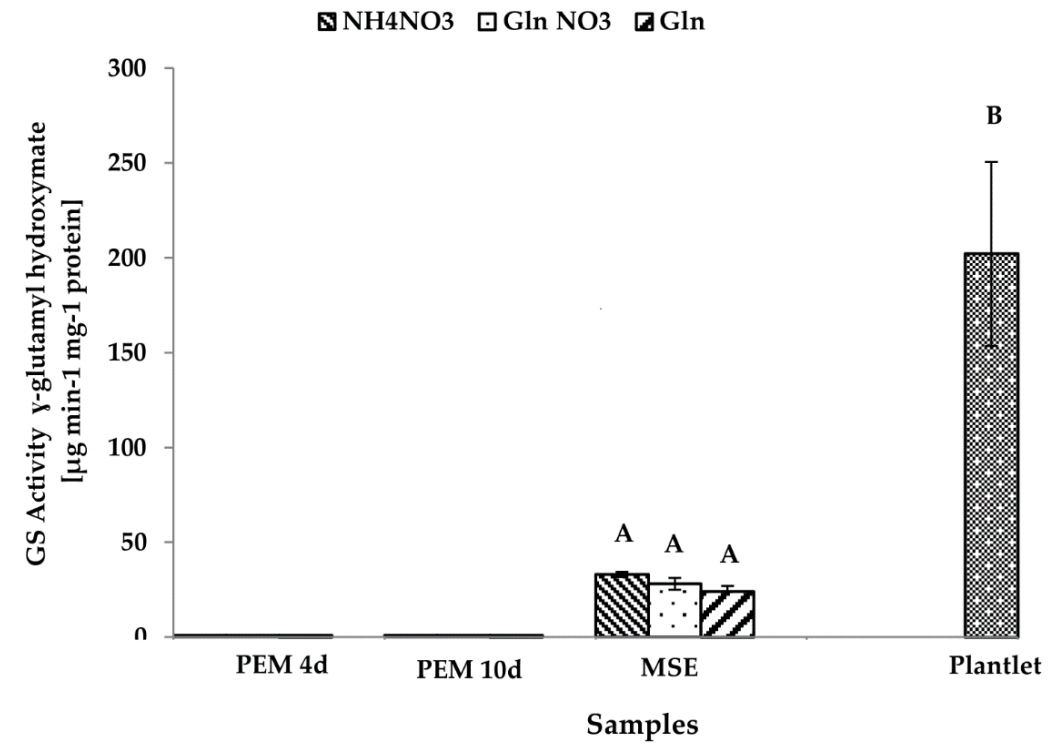

Figure 6. GS activity of PEMs after 4 days (PEM 4d) and after 10 days (PEM 10d) on standard or experimental media and of mature somatic embryos (MSE) generated on $\mathrm{NH}_{4}+\mathrm{NO}_{3}$ medium, $\mathrm{Gln}+\mathrm{NO}_{3}$ medium and Gln medium in comparison with two-month-old somatic embryo-derived plantlets. Bars indicate standard errors. Different letters above the columns indicate significant differences based on the Tukey-Kramer HSD test, $p \leq 0.05$.

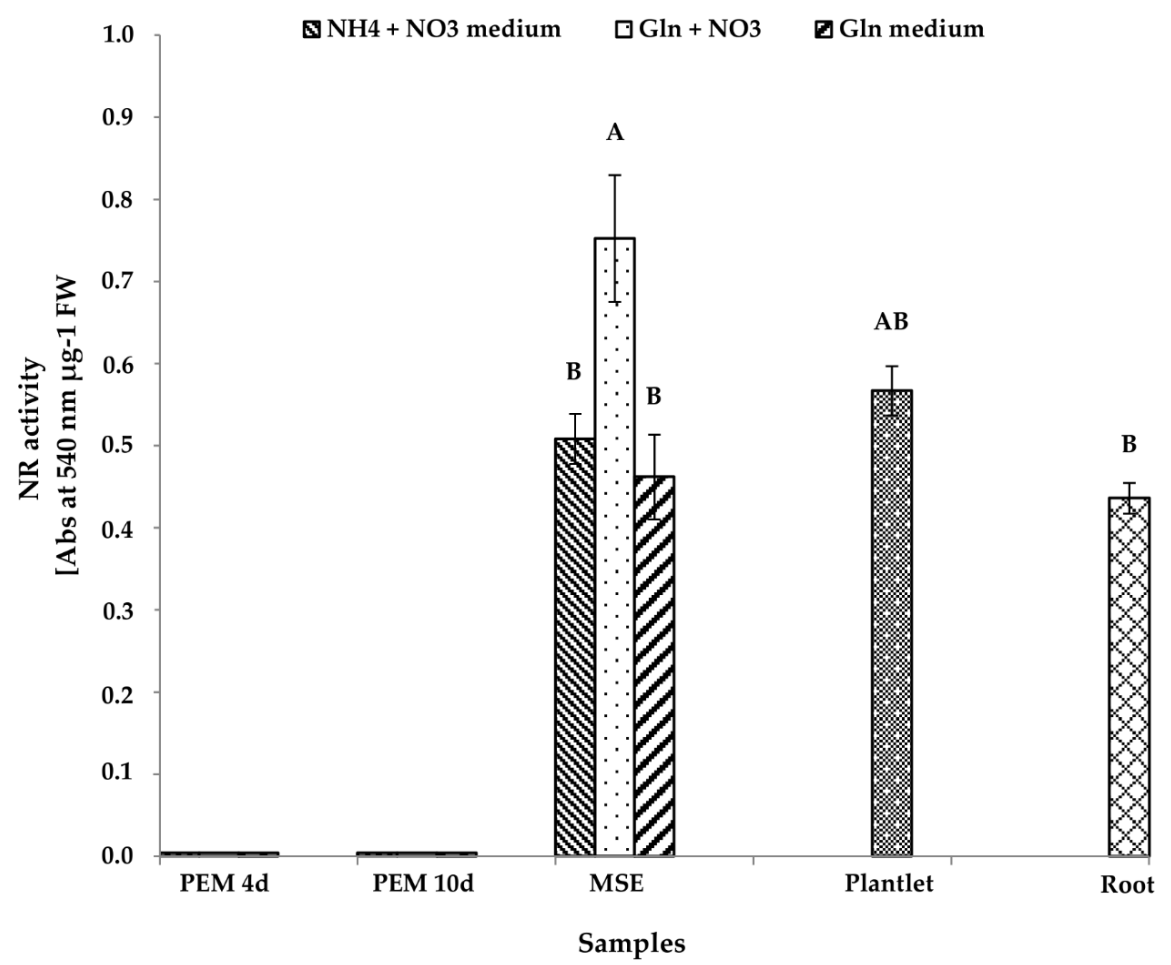

Figure 7. NR activity of PEMs after 4 days (PEM 4d) and after 10 days (PEM 10d) on standard or experimental media, mature somatic embryos (MSE) generated on $\mathrm{NH}_{4}+\mathrm{NO}_{3}$ medium, $\mathrm{Gln}+\mathrm{NO}_{3}$ medium and Gln medium and two-month-old somatic embryo-derived plantlets and roots. Bars indicate the standard error. Different letters above the columns indicate significant differences based on the Tukey-Kramer HSD test, $p \leq 0.05$. 


\subsubsection{Arginase Activity}

Arginase activity was observed in both PEMs and mature somatic embryos (Figure 8a,b). There was no statistically significant difference in the activity of arginase in PEMs after four days or after 10 days after transfer to standard or experimental media; however, arginase activity in PEMs was significantly higher than in somatic embryo-derived plantlets (Figure 8a). Mature somatic embryos generated on $\mathrm{Gln}+\mathrm{NO}_{3}$ medium as well as those on $\mathrm{NH}_{4}+\mathrm{NO}_{3}$ medium showed a significantly higher arginase activity than embryos matured on Gln medium (Figure 8b). The lower arginase activity in plantlets than in mature somatic embryos was statistically significant.

\subsection{Analysis of the Content of Ammonium and Amino Acids}

An aim of the analysis was to test if the absence of GS and NR activities in PEMs was related to an increase in the ammonium content, and changes in amino acid composition, of material grown on the ammonium-rich media, such as $\mathrm{NH}_{4}+\mathrm{NO}_{3}$. Analysis revealed differences between samples from cultures grown on the different media, notably regarding the ammonium, L-arginine, L-glutamine and L-glutamate content (Figure 9).

The ammonium content was significantly higher in PEMs than in mature somatic embryos $(p<0.001)$. For PEMs, the ammonium content was significantly higher $(p \leq 0.001)$ for PEMs grown on media containing ammonium ions than on $\mathrm{Gln}+\mathrm{NO}_{3}$ medium or Gln medium (Figure 9a). This is consistent with the lack of NR and GS activities in PEMs (Figures 6 and 7).

For PEMs the Gln/AA ratios were lowest as expected on $\mathrm{NH}_{4}+\mathrm{NO}_{3}$ medium, which lacked glutamine, but the differences were not significant (Figure $9 \mathrm{~b}$ ).

The Glu/AA rations are strikingly and significantly higher $(p<0.001)$ in mature somatic embryos than in PEMs (Figure 9c). This reflects the lack of GS activity in PEMs, and much higher GS activity in mature somatic embryos. The differences among the media were not significant.

Similarly, the Arginine/AA ratios are strikingly higher in mature somatic embryos than in PEMs (Figure 9d). The mature somatic embryos on Gln medium had a significantly higher $(p<0.01)$ Arginine/AA ratio than those grown on the $\mathrm{Gln}+\mathrm{NO}_{3}$ medium .

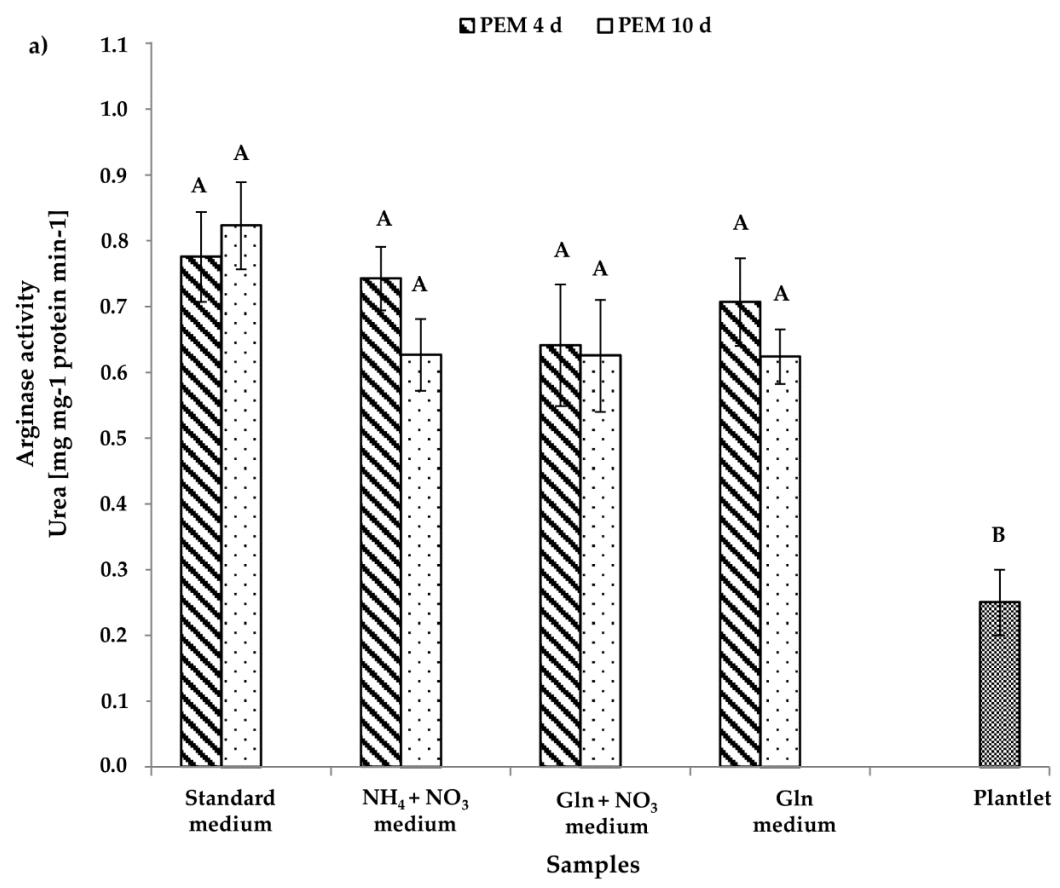

Figure 8. Cont. 


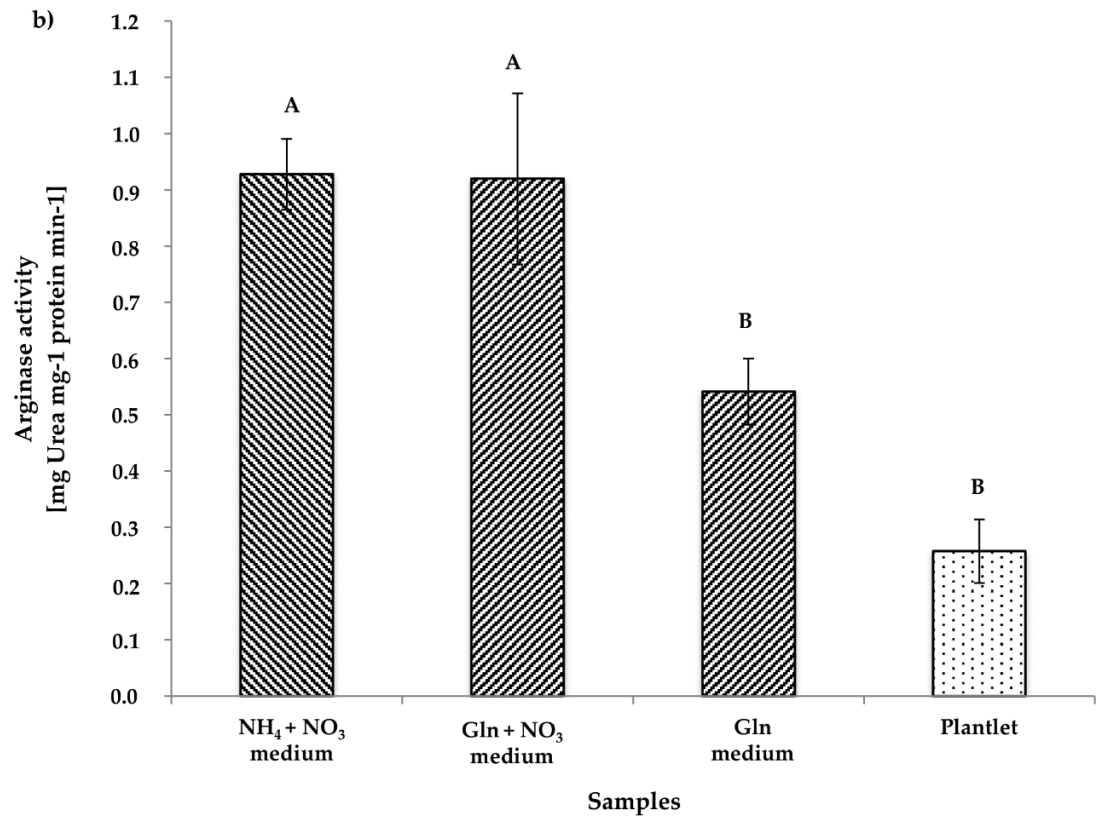

Figure 8. Arginase activity of PEMs and mature somatic embryos (MSE). (a) arginase activity of PEMs after 4 days (PEM 4d) and after 10 days (PEM 10d) on standard medium, $\mathrm{NH}_{4}+\mathrm{NO}_{3}$ medium, $\mathrm{Gln}+\mathrm{NO}_{3}$ medium and Gln medium in comparison with somatic embryo-derived plantlets run as control; (b) arginase activity of mature somatic embryos generated on $\mathrm{NH}_{4}+\mathrm{NO}_{3}$ medium, Gln $+\mathrm{NO}_{3}$ medium and Gln medium in comparison with two-month-old somatic embryo-derived plantlets. Bars indicate standard errors. Different letters above the columns indicate significant differences based on the Tukey-Kramer HSD test, $p \leq 0.05$.
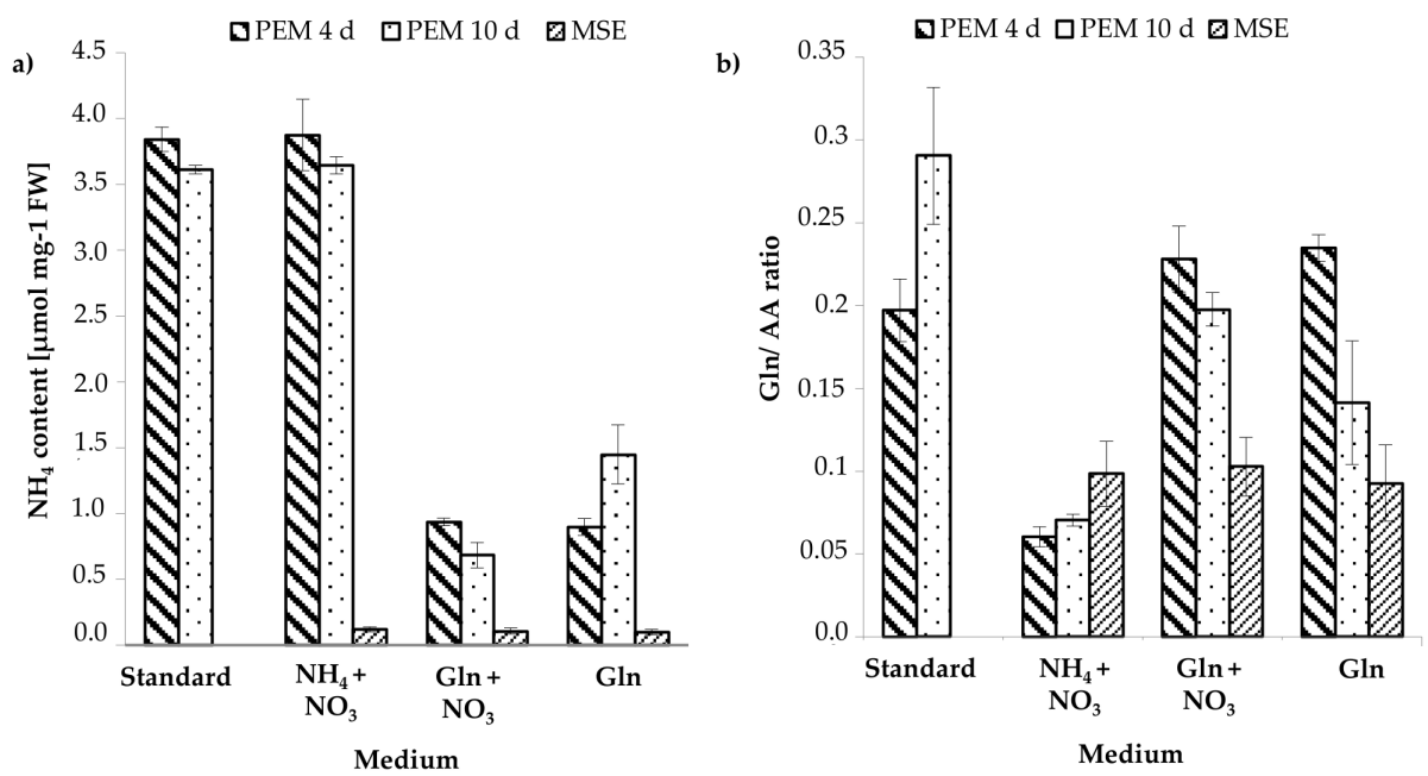

Figure 9. Cont. 

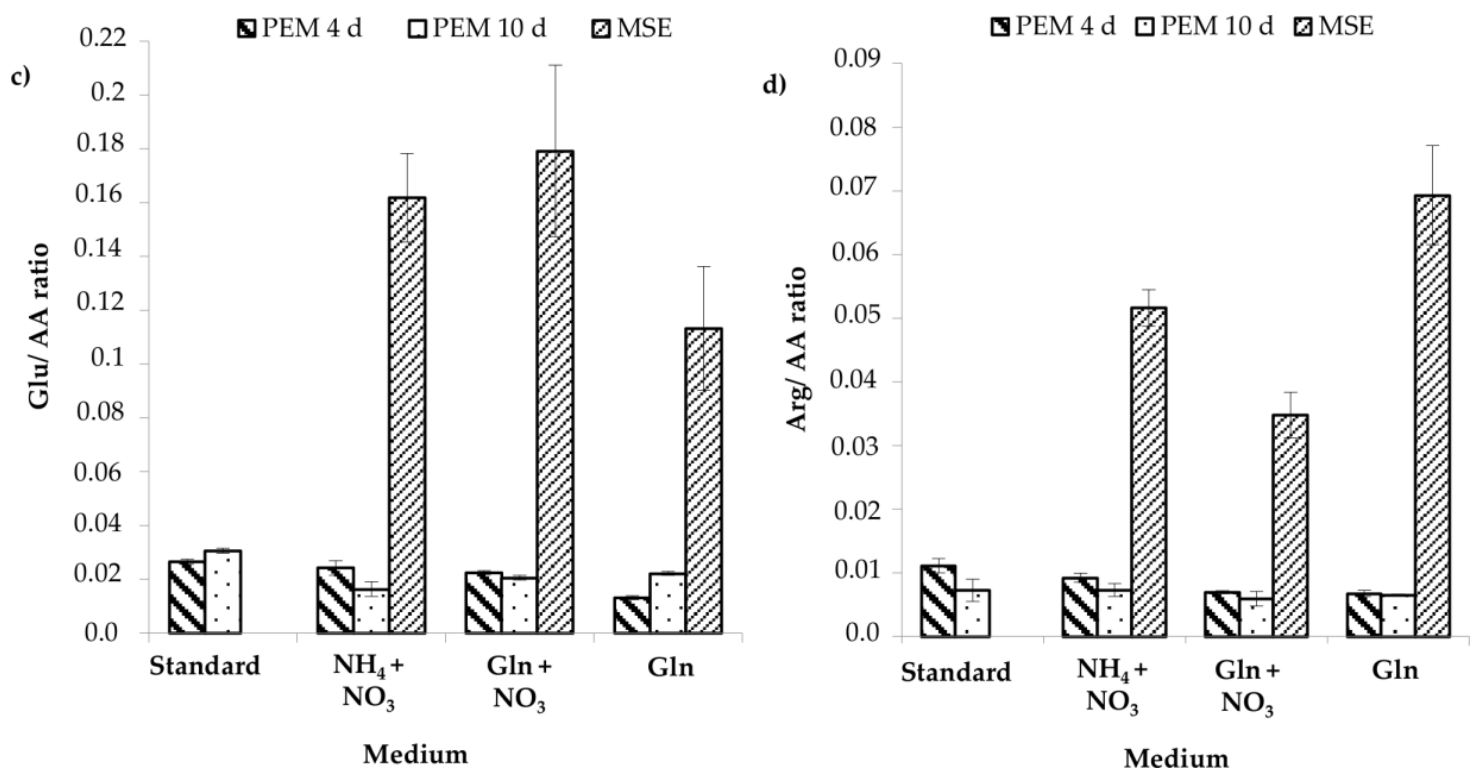

Figure 9. Ammonium and amino acid contents of PEMs four and ten days after transfer to standard medium, $\mathrm{NH}_{4}+\mathrm{NO}_{3}$, medium, $\mathrm{Gln}+\mathrm{NO}_{3}$ medium and Gln medium and mature somatic embryos (MSE) after six weeks on the corresponding maturation media. (a) ammonium contents per g FW; (b) L-glutamine content expressed as the ratio of L-glutamine: total amino acid content (Gln/AA); (c) L-glutamate content expressed as the ratio of L-glutamate: total amino acid content (Glu/AA); (d) L-arginine content expressed as the ratio of L-arginine: total amino acid content (Arg/AA). Bars indicate standard errors.

\section{Discussion}

\subsection{Morphological and Developmental Characterization, and Nitrogen Content}

Embryogenic cultures composed of PEMs grew significantly less on $\mathrm{NH}_{4}+\mathrm{NO}_{3}$ medium than on Gln $+\mathrm{NO}_{3}$ or Gln media. The amino acid L-glutamine is an important building block in the nitrogen metabolism of the plant and is the basis for purine, pyrimidine, nucleic acid, L-asparagine, L-histidine, L-tryptophane, L-arginine, and L-glutamate synthesis [24]. Embryogenic cultures grown without L-glutamine must synthesize this amino acid from the nitrogen sources available in the medium. This can be seen as an energetic disadvantage in comparison to PEM cultures which can take up the L-glutamine directly from the medium $[25,26]$, although energy is not a limiting factor if sucrose is supplied in the medium. The beneficial effect of L-glutamine on growth of cell cultures has been shown for several conifer species including Pseudotsuga menziesii (Mirb.) Franco [27], Pinus pinaster [28] and Pseudotsuga menziesii [29]. For Picea glauca, four times higher fresh weight increase on initiation medium was observed when L-glutamine was the sole source of nitrogen compared to growth on ammonium nitrate [30]. The increase in proliferation rates observed in media containing $\mathrm{NO}_{3}$ in addition to Gln could be due to the release of additional L-glutamine from metabolized nitrate, or by nitrate functioning as a growth promoting signal [31].

The appearances of the mature somatic embryos differed on the various media. The comparatively largest somatic embryos developed on the $\mathrm{Gln}+\mathrm{NO}_{3}$ medium. This is consistent with findings for Daucus carrota L., where somatic embryo development was improved if cultured on L-glutamine and nitrate in comparison to ammonium nitrate [32]. Furthermore, about twice the number of embryos was produced per gram PEM culture on Gln medium than on $\mathrm{NH}_{4}+\mathrm{NO}_{3}$ medium. This is in contrast to findings in Picea glauca, where no difference in embryo development and number from maturation on L-glutamine or ammonium nitrate was found [30], but in line with studies on Medicago sativa L. which showed that the addition of L-glutamine to the media led to both higher number and quality 
of the somatic embryos [33]. In Eucalyptus citriodora Hook, highly embryogenic cultures developed if L-glutamine and casein hydrolysate were added to the culture medium [34]. Also, in Picea mariana (Mill.) Britton, Sterns \& Poggenb., cultivation on medium containing L-glutamine as the sole nitrogen source resulted in a twofold increase in somatic embryo number compared to cultivation on ammonium nitrate [35].

Embryos matured on either $\mathrm{NH}_{4}+\mathrm{NO}_{3}$ or $\mathrm{Gln}+\mathrm{NO}_{3}$ medium displayed normal germination whereas embryos matured on Gln medium were swollen, showed weaker greening and no root emergence. Embryos from only the Gln medium had the highest internal Arg/AA ratio, suggesting a higher accumulation of L-arginine than in embryos matured on $\mathrm{NH}_{4}+\mathrm{NO}_{3}$ and Gln $+\mathrm{NO}_{3}$ media. Therefore one would assume a sufficient preparation for germination, owing to the importance of L-arginine as a compound in storage proteins for nourishment of germinating embryos [11,36]. Nitrate is important as a nutritional source but also as a signal controlling various aspects of plant growth and development including the supplies of cytokinin and auxin (reviewed by [37-39]. Plants suffering from nitrogen limitation often display a weak greening, suggesting that the lack of nitrate caused the impaired germination, either due to the absence of nitrate signaling functions or to nitrogen deficiency [40].

The relatively slower growth rate of PEM cultures on $\mathrm{NH}_{4}+\mathrm{NO}_{3}$ medium lacking L-glutamine did not relate to germination success as germinants also developed on this medium. This is likely due to the benefit of an active GS during the maturation stage, increasing the ammonium tolerance [41] and enabling utilization of the inorganic nitrogen sources in the medium, which is reflected by the similar high Gln/AA ratio in mature embryos on all three media.

In the present study, both the standard medium and the $\mathrm{NH}_{4}+\mathrm{NO}_{3}$ medium were supplemented with a similar amount of ammonium. Distinctly higher ammonium contents of the PEMs grown on these two media were observed, which are likely to counteract the positive effect of L-glutamine and possibly accumulate to toxic levels. Studies with Pinus strobus L. revealed a total inhibition of callus growth if ammonium was the only nitrogen source available [42], and Oryza sativa L. suspension cultures showed inhibited growth if given ammonium [43]. Furthermore, Citrus sinensis (L.) Osbeck embryogenic callus growth was significantly reduced if the majority of inorganic nitrogen was supplied as ammonium [44]. Another study carried out with Oryza sativa cells found that L-glutamine supplementation had no positive effect on the internal ammonium content [45].

\subsection{Enzyme Activities}

No GS or NR activity was observed in PEMs regardless of the nitrogen composition of the medium. This is consistent with negligible growth of PEMs on media lacking organic nitrogen. Interestingly, gene expression of NR and GS has been detected in PEM cultures (Carlsson 2014, unpublished). This implies post-transcriptional control of NR and GS; if the mRNA is translated, the resulting proteins are inactive enzymatically. In the present study, autoclaved casein hydrolysate in the medium enabled survival of the PEMs and limited growth, but proliferation increased if L-glutamine was added. Since NR activity in PEMs apparently is very low, utilization of nitrate given in the $\mathrm{NH}_{4}+\mathrm{NO}_{3}$ medium would be suboptimal [9,12], affecting the growth of PEMs. This would also be the case if GS was inactive in PEMs. GS is required to assimilate the ammonium resulting from nitrate and nitrite reduction and to assimilate ammonium provided in the medium [9,12], and PEMs grown on $\mathrm{NH}_{4}+\mathrm{NO}_{3}$ medium exhibited a distinctively lower Gln/AA ratio than PEMs grown on media containing L-glutamine. L-glutamine is an important building block and constantly needed in the metabolism of the plant $[10,24]$. The increase in the Gln/AA ratio after ten days on medium without an external L-glutamine source may indicate some degree of GS activity in the PEMs or synthesis of glutamine from the amino-acids in the casein hydrolysate by aminotransferases/transaminases. It was previously shown that cell-line 11:12:02 proliferates well on L-asparagine as the sole source of organic nitrogen (Clapham D., unpublished). 
In contrast to GS and NR, arginase enzyme activity could be detected in PEMs. Arginase is important for protein breakdown and recycling of stored nitrogen [11,36]. The greater abundance of an enzyme related to nitrogen recycling (arginase) than to the primary incorporation of nitrogen (NR, GS) can be related to the nutrition of the original embryonic tissue in the conifer seed. It is likely that the early stage embryo is fed with L-arginine, L-glutamine and perhaps other transport amino acids. Arginase is required for the synthesis of L-ornithine, from which proline can also be synthesized, see [46]. The arginase activity in PEM cultures was not notably affected by the nitrogen source the cultures were grown on, but was significantly higher than the arginase activity in somatic embryo-derived plantlets. This is confirmed with studies of Pinus taeda L., where arginase activity was shown to be negligible in seedlings [47].

NR activity was detected in mature somatic embryos generated on all media with different nitrogen sources. NR is regulated by many factors both at the transcriptional level and the enzyme activity. A lack of carbon that may occur in darkness owing to inactivity of photosynthetic machinery results in NR being down-regulated and phosphorylated [46,47]. However, if carbon in the form of sucrose is present in darkness, the activity of the NR increases. This could explain the presence of active NR on Gln medium without a nitrate source. Nitrate itself is also a factor up-regulating gene transcription and enzyme activity of NR [46], leading to the presence of active $\mathrm{NR}$ on $\mathrm{NH}_{4}+\mathrm{NO}_{3}$ medium. NR activity in 2-month-old somatic embryo-derived plants, containing both shoots and roots, is slightly higher than in the samples from plant roots alone, revealing a high degree of NR activity in roots. This is consistent with findings in many plant species including conifers [40]. Somatic embryo-derived plantlets and roots were selected as positive controls for the functionality of the enzyme assay as they have previously demonstrated NR activity [21].

GS activity could be measured in mature somatic embryos developed on all three media tested. Maturation on $\mathrm{NH}_{4}+\mathrm{NO}_{3}$ without a source of L-glutamine implies the production of glutamine by the embryos themselves. For incorporation of nitrate and ammonium into L-glutamine, GS activity is required [9]. Ammonium is known to up-regulate GS-activity levels in Pseudotsuga menziesii [48], and nitrate abundance affects GS at the transcriptional level [46]. GS activity detected in embryos matured on Gln medium can be related to its importance for the assimilation of ammonium. Some of the sources for ammonium release are protein synthesis and breakdown. Moreover, GS functions together with glutamine oxoglutarate aminotransferase (GOGAT) to provide the basis for synthesis of, for instance, L-ornithine, L-glutamate and L-asparagine [9]. The GS activity detected in mature somatic embryos developed on Gln medium is therefore likely related to the metabolic importance of the enzyme. Furthermore, L-glutamine is known to be chemically unstable in nutrient media and one of the breakdown products is ammonium [49] that can be taken up by the cultures, which in turn needs GS activity for assimilation [9,12]. The notably reduced amount of ammonium in mature somatic embryos compared to PEMs, especially on $\mathrm{NH}_{4}+\mathrm{NO}_{3}$ medium, indicates the development of a more effective ammonium assimilation during somatic embryogenesis, presumably due to increasing GS activity. The comparatively high GS activity in the 2-month old somatic embryo-derived plantlets can be explained by the important function of GS1a in detoxifying photorespiratory ammonium in photosynthetic active tissues [50].

Arginase activity is only marginally higher in mature embryos than in PEMs, but the internal L-arginine content is about five times higher. This indicates a similar degree of protein recycling via the arginase during proliferation and maturation, but at the same time, a higher degree of L-arginine synthesis or lesser use than at the proliferation stage. One possible building block for L-arginine is L-ornithine, which in turn is synthesised from L-glutamate [9]. This coincides with a detected higher Glu/AA ratio in somatic embryos than in PEMs while the Gln/AA ratio remained similar. The higher L-glutamate content in mature embryos than in PEMs is presumably metabolized further, likely also to L-arginine, explaining the higher Arg/AA ratio during the maturation stage. The increase in the Arg/AA ratio in somatic embryos compared to PEMs is in line with studies in Daucus carota showing a peak of the internal L-arginine content during globular and torpedo stage somatic embryos [32]. 
The generally higher Arg/AA ratio in mature somatic embryos than in PEM cultures is presumably due to the role of L-arginine in storage protein composition of conifer seeds [11,36]. In Pinus taeda, nearly half of the storage reserves in the megagametophyte is composed of L-arginine [47]. As a result, L-arginine is believed to accumulate in mature somatic embryos in order to ensure provision of, e.g., L-ornithine for further amino acid synthesis [51], for feeding the germinating embryo. Somatic embryos matured on Gln medium showed significantly lower arginase activity than embryos developed on both $\mathrm{NH}_{4}+\mathrm{NO}_{3}$ and $\mathrm{Gln}+\mathrm{NO}_{3}$. The lower arginase activity in somatic embryos developed on Gln medium corresponds with their higher Arg/AA ratio. This suggests a higher amount of L-arginine in mature somatic embryos developed on Gln medium in comparison to embryos obtained on both ammonium plus nitrate and $\mathrm{Gln}+\mathrm{NO}_{3}$ medium. Furthermore, a high content of the storage protein-related amino-acid L-arginine would be expected to improve germination. In Medicago sativa, addition of L-glutamine to the maturation medium resulted in higher storage protein accumulation of somatic embryos [52].

\section{Conclusions}

PEMs do not proliferate on media lacking organic nitrogen. In the present study, it was demonstrated that the reduced growth of PEMs on medium containing only $\mathrm{NH}_{4}+\mathrm{NO}_{3}$, as compared to medium supplemented with L-glutamine (Gln; $\mathrm{Gln}+\mathrm{NO}_{3}$ media), was associated with absence of detectable GS and NR activities. This can be related to the preferential uptake at this stage of glutamine rather than nitrate and ammonium reported by [15]. Detectable levels of GS and NR activity were however found in mature somatic embryos, suggesting an increase in enzyme activities compared to those in PEMs. Mature somatic embryos could also be produced on $\mathrm{NH}_{4}+\mathrm{NO}_{3}$ medium. However, the largest and most developed mature somatic embryos were achieved by culture on $\mathrm{Gln}+\mathrm{NO}_{3}$ medium, which combines a reduced (L-glutamine) and an unreduced (nitrate) form of nitrogen, leading to the best germination rates and healthiest SE-plantlets.

Supplementary Materials: The following is available online at http:/ www.mdpi.com/1999-4907/9/6/288/s1, Figure S1: GS activity in cell line 11:07:01.

Author Contributions: J.D., D.C. and U.E. conceived and designed the experiments; J.D. performed the experiments; J.D., D.C. and U.E. analyzed the data and wrote the paper.

Acknowledgments: This research was supported by funding from UPSC Berzelii Centre for Forest Biotechnology in Umeå, Sweden. We thank Edward Businge for his advice regarding the enzyme assays. We are grateful to SweTree Technologies for the donation of plants, and to the Swedish Metabolomics Centre for amino acids and ammonium analysis.

Conflicts of Interest: The authors declare no conflict of interest.

\section{References}

1. Rosvall, O. Review of the Swedish Tree Breeding Programme; Forest Research Institute of Sweden: Uppsala, Sweden, 2011; pp. 1-88.

2. Lindgren, D. A Way to Utilize the Advantages of Clonal Forestry for Norway Spruce? Working Papers of the Finnish Forest Research Institute: Vantaa, Finland, 2008; Volume 114, pp. 8-15.

3. Funda, T.; Wennström, U.; Almqvist, C.; Andersson Gull, B.; Wang, X.-A. Mating dynamics of Scots pine in isolation tents. Tree Genet. Genomes 2016, 12, 112. [CrossRef]

4. Öhlund, J.; Näsholm, T. Growth of conifer seedlings on organic and inorganic nitrogen sources. Tree Physiol. 2001, 21, 1319-1326. [CrossRef] [PubMed]

5. Persson, J.; Gardeström, P.; Näsholm, T. Uptake, metabolism and distribution of organic and inorganic nitrogen sources by Pinus sylvestris. J. Exp. Bot. 2006, 57, 2651-2659. [CrossRef] [PubMed]

6. Gruffman, L.; Ishida, T.; Nordin, A.; Näsholm, T. Cultivation of Norway spruce and Scots pine on organic nitrogen improves seedling morphology and field performance. For. Ecol. Manag. 2012, 276, 118-124. [CrossRef] 
7. Kronzucker, H.J.; Siddiqi, M.; Glass, A. Conifer root discrimination against soil nitrate and the ecology of forest succession. Nature 1997, 385, 59-61. [CrossRef]

8. Gruffman, L.; Jämtgård, S.; Näsholm, T. Plant nitrogen status and co-occurrence of organic and inorganic nitrogen sources influence root uptake by Scots pine seedlings. Tree Physiol. 2014, 34, 205-213. [CrossRef] [PubMed]

9. Mérigout, P.; lelandais, M.; Bitton, F.; Renou, J.P.; Briand, X.; Meyer, C.; Daniel-Vedele, F. Physiological and transcriptomic aspects of urea uptake and assimilation in Arabidopsis plants. Plant Physiol. 2008, 147, 1225-1238. [CrossRef] [PubMed]

10. Miflin, B.J.; Habash, D.Z. The role of glutamine synthetase and glutamate dehydrogenase in nitrogen assimilation and possibilities for improvement in nitrogen utilization of crops. J. Exp. Bot. 2002, 53, 979-987. [CrossRef]

11. Pérez-Rodríguez, M.J.; Suárez, M.F.; Heredia, R.; Ávila, C.; Breton, D.; Trontin, J.F.; Filonova, L.; Bozhkov, P.; von Arnold, S.; Harvengt, L.; et al. Expression patterns of two glutamine synthetase genes in zygotic and somatic pine embryos support specific roles in nitrogen metabolism during embryogenesis. New Phytol. 2006, 169, 35-44. [CrossRef] [PubMed]

12. Joy, R.W., IV; Vogel, H.J.; Thorpe, T.A. Inorganic nitrogen metabolism in embryogenic white spruce cultures: A nitrogen 14/15 NMR study. J. Plant Physiol. 1997, 151, 306-315. [CrossRef]

13. Buchmann, N.; Schulze, E.D.; Gebauer, G. ${ }^{15} \mathrm{~N}$-ammonium and ${ }^{15} \mathrm{~N}$-nitrate uptake of a 15 -year-old Picea abies plantation. Oecologia 1995, 102, 361-370. [CrossRef] [PubMed]

14. Von Arnold, S.; Clapham, D. Spruce embryogenesis. In Plant Embryogenesis: Methods in Molecular Biology; Suarez, M.F., Bozhkov, P.V., Eds.; Human Press: Totowa, NJ, USA, 2008; Volume 427, pp. 31-47.

15. Carlsson, J.; Svennerstam, H.; Moritz, T.; Egertsdotter, U.; Ganeteg, U. Nitrogen uptake and assimilation in proliferating embryogenic cultures of Norway spruce-Investigating the specific role of glutamine. PLoS ONE 2017, 12, e0181785. [CrossRef] [PubMed]

16. Larsson, E.; Sundström, J.F.; Sitbon, F.; von Arnold, S. Expression of PaNAC01, a Picea abies CUP-SHAPED COTYLEDON orthologue, is regulated by polar auxin transport and associated with differentiation of the shoot apical meristem and formation of separated cotyledons. Ann. Bot. 2012, 110, 923-934. [CrossRef] [PubMed]

17. Kvaalen, H.; Appelgren, M. Light quality influences germination, root growth and hypocotyl elongation in somatic embryos but not in seedlings of Norway spruce. In Vitro Cell. Dev. Biol. Plant 1999, 35, 437-441. [CrossRef]

18. Canovas, F.M.; Canton, F.R.; Gallardo, F.; García-Gutiérrez, A.; de Vicente, A. Accumulation of glutamine synthestase during early development of maritime pine (Pinus pinaster) seedlings. Planta 1991, 185, 372-378. [CrossRef] [PubMed]

19. Canovas, F.; Valpuesta, V.; Castro, I.N. Characterization of tomato leaf glutamine synthetase. Plant Sci. Lett. 1984, 37, 79-85. [CrossRef]

20. Park, B.S.; Song, J.T.; Seo, H.S. Arabidopsis nitrate reductase activity is stimulated by the E3 SUMO ligase AtSIZ1. Nat. Commun. 2011, 2, 400. [CrossRef] [PubMed]

21. Andrews, M. The partitioning of nitrate assimilation between root and shoot of higher plants. Plant Cell Environ. 1986, 9, 511-519.

22. Geyer, J.W.; Dabich, D. Rapid method for determination of arginase activity in tissue homogenates. Anal. Biochem. 1971, 39, 412-417. [CrossRef]

23. Martín-Falquina, A.; Legaz, M.E. Purification and properties of constitutive arginase of Evernia prunastri. Plant Physiol. 1984, 76, 1065-1069. [CrossRef] [PubMed]

24. Miflin, B.J.; Lea, P.J. Amino acid metabolism. Ann. Rev. Plant Physiol. 1977, 28, 299-329. [CrossRef]

25. Durzan, D.J. Nitrogen metabolism and vegetative propagation of forest trees. In Tissue Culture in Forestry; Bonga, J.M., Durzan, D.J., Eds.; Martinus Nijhoff/Dr. W. Junk Publishers: Dordrecht, The Netherlands; Boston, MA, USA; Lancaster, UK, 1981; pp. 256-324.

26. Zerihun, A.; McKenzie, B.A.; Morton, J.D. Photosynthate costs associated with the utilization of different nitrogen-forms: Influence on the carbon balance of plants and shoot-root biomass partitioning. New Phytol. 1998, 138, 1-11. [CrossRef]

27. Leustek, T.; Kirkby, E.G. The influence of glutamine on growth and viability of cell suspension cultures of Douglas-fir after exposure to polyethylene glycol. Tree Physiol. 1987, 4, 371-380. [CrossRef] 
28. David, H.; Jarlet, E.; David, A. Effects of nitrogen source, calcium concentration and osmotic stress on protoplasts and protoplast-derived cell cultures of Pinus pinaster cotyledons. Physiol. Plant. 1984, 61, 477-482. [CrossRef]

29. Kirby, E.G. The effects of organic nitrogen sources on growth of cell cultures of Douglas-fir. Physiol. Plant. 1982, 56, 114-117. [CrossRef]

30. Barett, J.D.; Park, Y.S.; Bonga, J.M. The effectiveness of various nitrogen sources in white spruce [Picea glauca (Moench) Voss] somatic embryogenesis. Plant Cell Rep. 1997, 16, 411-415.

31. Forsum, O.; Svennerstam, H.; Ganeteg, U.; Näsholm, T. Capacities and constraints of amino acid utilization in Arabidopsis. New Phytol. 2008, 179, 1058-1069. [PubMed]

32. Higashi, K.; Kamada, H.; Harada, H. The effects of reduced nitrogenous compounds suggests that glutamine synthetase activity is involved in the development of somatic embryos in carrot. Plant Cell Tissue Organ Cult. 1996, 45, 109-114. [CrossRef]

33. Stuart, D.; Strickland, S. Somatic embryogenesis from cell cultures of Medicago sativa L. II. The interaction of amino acids with ammonium. Plant Sci. Lett. 1984, 34, 175-181.

34. Muralidharan, E.M.; Gupta, P.K.; Mascarenhas, A.F. Plantlet production through high frequency somatic embryogenesis in long term cultures of Eucalyptus citriodora. Plant Cell Rep. 1989, 8, 41-43. [CrossRef] [PubMed]

35. Khlifi, S.; Tremblay, F.M. Maturation of black spruce somatic embryos. Part I. Effect of L-glutamine on the number and germinability of somatic embryos. Plant Cell Tissue Organ Cult. 1995, 41, 23-32.

36. Feirer, R. The biochemistry of conifer embryo development: Amino acids, polyamines and storage proteins. In Somatic Embryogenesis in Woody Plants; Jain, S., Gupta, P., Newton, R., Eds.; Kluwer Academic Press: Dordrecht, The Netherlands, 1995; Volume 1, Chapter 15; pp. 317-336.

37. Crawford, N.M. Nitrate: Nutrient and signal for plant growth. Plant Cell 1995, 7, 859-868. [CrossRef] [PubMed]

38. Krouk, G.; Crawford, G.; Coruzzi, G.M.; Tsay, Y.F. Nitrate signalling: Adaptation to fluctuating environments. Curr. Opin. Plant Biol. 2010, 13, 266-273. [CrossRef] [PubMed]

39. Sakakibara, H.; Takei, K.; Hirose, N. Interactions between nitrogen and cytokinin in the regulation of metabolism and development. Trends Plant Sci. 2006, 11, 440-448. [CrossRef] [PubMed]

40. Hawkesford, M.; Horst, W.; Kichey, T.; Lambers, H.; Schjoerring, J.; Møller, I.S.; White, P. Functions of macronutrients. In Mineral Nutrition of Higher Plants, 3rd ed.; Marschner, P., Ed.; Academic Press: Cambridge, MA, USA, 2012; pp. 135-189.

41. Cruz, C.; Bio, A.F.M.; Dominguez-Valdivia, M.D.; Aparicio-Tejo, P.M.; Lamsfus, C.; Martins-Loução, M.A. How does glutamine synthetase activity determine plant tolerance to ammonium? Planta 2006, 223, 1068-1080. [CrossRef] [PubMed]

42. Kaul, K.; Hoffman, S.A. Ammonium ion inhibition of Pinus strobus L. callus growth. Plant Sci. 1993, 88, 169-173. [CrossRef]

43. Chen, S.J.; Kao, C.H. Polyamines in relation to ammonium-inhibited growth in suspension-cultured rice cells. Bot. Bull. Acad. Sin. 1996, 37, 197-200.

44. Niedz, R.P. Growth of embryogenic sweet organge callus on media varying in the ratio of nitrate to ammonium nitrogen. Plant Cell Tissue Organ Cult. 1994, 39, 1-5. [CrossRef]

45. Chen, S.J.; Kao, C.H. Ammonium-inhibited growth of suspension-cultured rice cells as affected by medium pH. Plant Growth Regul. 1997, 21, 1-6. [CrossRef]

46. Buchanan, B.B.; Gruissem, W.; Jones, L. Interaction between nitrate assimilation and carbon metabolism. In Biochemistry and Molecular Biology of Plants; Wiley: Hoboken, NJ, USA, 2000; Chapter 16; pp. 786-849.

47. King, J.E.; Gifford, D.J. Amino acid utilization in seeds of loblolly pine during germination and early seedling growth (I. Arginine and arginase activity). Plant Physiol. 1997, 113, 1125-1135. [CrossRef] [PubMed]

48. Bedell, J.P.; Chalot, M.; Garnier, A.; Botton, B. Effects of nitrogen source on growth and activity of nitrogen-assimilating enzymes in Douglas-fir seedlings. Tree Physiol. 1999, 19, 205-210. [CrossRef] [PubMed]

49. Tritsch, G.L.; Moore, G.E. Spontaneous decomposition of glutamine in cell culture media. Exp. Cell Res. 1962, 28, 360-364. [CrossRef]

50. Cantón, F.R.; Suarez, M.F.; José-Estanyol, M.; Cánovas, F.M. Expression analysis of a cytosolic glutamine synthetase gene in cotyledons of Scots pine seedlings: Developmental light-dark regulation and spatial distribution of specific transcripts. Plant Mol. Biol. 1999, 40, 623-634. [CrossRef] [PubMed] 
51. Slocum, R.D. Genes, enzymes and regulation of arginine biosynthesis in plants. Plant Physiol. Biochem. 2005, 43, 729-745. [CrossRef] [PubMed]

52. Lai, F.M.; Senaratna, T.; McKersie, B.D. Glutamine enhances storage protein synthesis in Medicago sativa L. somatic embryos. Plant Sci. 1992, 87, 69-77. [CrossRef] 